\title{
Experimental Study on Influence of Baume Degrees on Double Liquid Grouting Material's Consolidation Strength
}

\author{
Yanfang $\mathrm{Li}^{\mathrm{a}}$, Hongliang Huang ${ }^{\mathrm{b}}$ and Pingyin Yang ${ }^{\mathrm{c}}$ \\ Hebei University of Architecture, Zhangjiakou 075000, China

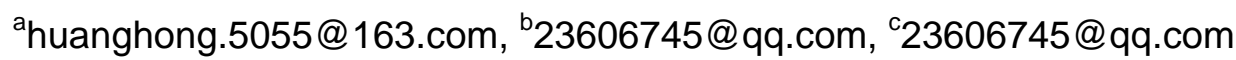

Keywords: Baume degrees, Grouting material, Consolidation strength, Experimental study

\begin{abstract}
In the premise of selecting different consistency of cement slurry, deploy different concentrations of Sodium silicate, design 16 groups of ratio, design and test research on cement and Sodium silicate double liquid grouting material mixture ratio, through the collation and analysis of experimental data, obtained the relationship of the Sodium silicate Baume influencing on cement-Sodium silicate double liquid grouting material's consolidation strength.
\end{abstract}

\section{Introduction}

With the rapid development of the research methods of building materials and testing technology, in the collapsible loess's foundation reinforcement, the formulation composition, construction technology and using performance of grouting material have been greatly developed and improved. Cement-Sodium silicate grouting material in this research (i.e. C-S double liquid grouting material) is one of the advanced grouting materials commonly used in building foundation reinforcement engineering. It uses cement, Sodium silicate as the main agent (if necessary, adding additives), will both proportionally and respectively pump mixed, then injection of grouting process of formation.

\section{Test Materials and Equipment}

Raw Materials. The main test parameters of raw materials used in this project and its basic properties(Table 1).

Table 1 Raw materials

\begin{tabular}{lll}
\hline Name of the raw materials & Manufacturers & $\begin{array}{l}\text { Performance parameters of raw } \\
\text { materials }\end{array}$ \\
\hline P.O 42.5 cement & Zhangjiakou jinyu cement co., LTD & $\begin{array}{l}3 \mathrm{~d}: \mathrm{f}_{\mathrm{tm}}=5.0 \mathrm{MPa}, \mathrm{f}_{\mathrm{c}}=23.8 \mathrm{MPa} \\
28 \mathrm{~d}: \mathrm{f}_{\mathrm{tm}}=8.0 \mathrm{MPa}, \mathrm{f}_{\mathrm{c}}=47.0 \mathrm{MPa}\end{array}$ \\
Sodium silicate & Zhangjiakou qiaoxi yongsheng chemical plant & Modulus $\mathrm{n}=2.8$, Baume ${ }^{0}$ Bé=37 \\
\hline
\end{tabular}

Equipments. The main equipments used in this subject(Table 2).

\section{Experimental Research}

Test scheme. In the actual application in construction engineering, in order to make the C-S double liquid grouting slurry material have good sealing effect, in addition to control the gel time of C-S double solution grouting slurry, still need to strictly control the consolidation strength of the grouting concretion body. The consolidation strength is connected with the types of cement, cement slurry consistency (i.e., water cement ratio, W/C), the concentration of Sodium silicate (i.e. Baume ${ }^{0} \mathrm{Bé}$ ), cement and Sodium silicate volume ratio, the types and admixture of additives and admixture and species of admixture and other factors. The subject of experimental research on mixture ratio design: select the P.O 42.5 cement, cement and Sodium silicate volume ratio is $1: 1$, cement slurry W/C is $0.6,0.7,0.8,0.9,{ }^{0}$ Bé of Sodium silicate is $21,25,29,33$, combine into 16 groups ratio for determination of consolidation strength. 
Table 2 Equipments

\begin{tabular}{|c|c|c|}
\hline Name of equipments & Specification & Manufacturer \\
\hline Medical balance & $\mathrm{HC} \cdot \mathrm{TP} 11 \mathrm{~B} \cdot 10$ & Beijing Medical Balance Factory \\
\hline Cement paste mixer & ST-160 & Shenyang Beifang Testing Instrument Factory \\
\hline Baume meter & ${ }^{0}$ Bé:0-70, length: $23 \mathrm{~cm}$ & Huanghua Automation Instrument Factory \\
\hline The cement triple test mortar & $40 \times 40 \times 160$ & $\begin{array}{l}\text { Hebei Beifang Building Instrument } \\
\text { Manufacturing Limited Company }\end{array}$ \\
\hline $\begin{array}{l}\text { Standard temperature and } \\
\text { humidity curing box }\end{array}$ & HY-40B & $\begin{array}{l}\text { China Botou Kexi Instrument Equipment } \\
\text { Factory }\end{array}$ \\
\hline $\begin{array}{l}\text { Standard curing room constant } \\
\text { temperature and humidity } \\
\text { Automatic equipment }\end{array}$ & HWB-6 & Beijing Jingqiang Equipment Factory \\
\hline Electric bending apparatus & KZJ-5 & Shenyang Precision Instrument Factory \\
\hline $\begin{array}{l}\text { Electro hydraulic pressure testing } \\
\text { machine (precision of } 1 \text { grade) }\end{array}$ & WAY-600 & $\begin{array}{l}\text { Wuxi Tin Instrument Building Material } \\
\text { Factory }\end{array}$ \\
\hline
\end{tabular}

Experimental Data. The designed mixture ratio of C-S double liquid grouting material(Table 3 ), by the experimental study of double liquid grouting materials $7 \mathrm{~d}$ and $28 \mathrm{~d}$ consolidation strength measured(Table 4 and Table 5).

Table 3 Proportion of double fluid grouting material

\begin{tabular}{lllll}
\hline \multirow{2}{*}{$\begin{array}{l}\text { Serial number of } \\
\text { mixture ratio }\end{array}$} & Number of mixture ratio & \multicolumn{2}{l}{ Cement slurry(1000ml) } & Sodium silicate(ml) \\
\cline { 3 - 4 } & & Cement (g) & Water(ml) & \\
\hline H01 & C6V1.0S21+N & 1100 & 660 & 1000 \\
H02 & C6V1.0S25+N & 1100 & 660 & 1000 \\
H03 & C6V1.0S29+N & 1100 & 660 & 1000 \\
H04 & C6V1.0S33+N & 1100 & 660 & 1000 \\
H05 & C7V1.0S21+N & 993 & 695 & 1000 \\
H06 & C7V1.0S25+N & 993 & 695 & 1000 \\
H07 & C7V1.0S29+N & 993 & 695 & 1000 \\
H08 & C7V1.0S33+N & 993 & 695 & 1000 \\
H09 & C8V1.0S21+N & 900 & 720 & 1000 \\
H10 & C8V1.0S25+N & 900 & 720 & 1000 \\
H11 & C8V1.0S29+N & 900 & 720 & 1000 \\
H12 & C8V1.0S33+N & 900 & 720 & 1000 \\
H13 & C9V1.0S21+N & 850 & 765 & 1000 \\
H14 & C9V1.0S25+N & 850 & 765 & 1000 \\
H15 & C9V1.0S29+N & 850 & 765 & 1000 \\
H16 & C9V1.0S33+N & 850 & 765 & 1000 \\
\hline
\end{tabular}

Description: meaning of symbols in the number of mixture ratio in the follow:

C--indicate the cement slurry;

$6,7,8,9$--indicate the cement slurry water cement ratio, that is, W/C are $0.6,0.7,0.8,0.9$;

V1.0--indicate the volume of Sodium silicate was 1 time cement slurry;

S--indicate Sodium silicate;

21, 25, 29, 33--indicate the Baume of Sodium silicate, that is ${ }^{0}$ Bé are 21, 25, 29, 33;

$\mathrm{N}$--indicate donot add additive and admixture. 
Table $47 \mathrm{~d}$ consolidation strength of double fluid grouting material

\begin{tabular}{|c|c|c|c|c|c|c|c|}
\hline \multirow{2}{*}{$\begin{array}{l}\text { Serial } \\
\text { number of } \\
\text { mixture } \\
\text { ratio }\end{array}$} & \multirow{2}{*}{$\begin{array}{l}\text { Number of } \\
\text { mixture ratio }\end{array}$} & \multicolumn{2}{|c|}{$\begin{array}{l}\text { 7d consolidation } \\
\text { strength(MPa) }\end{array}$} & \multirow{2}{*}{$\begin{array}{l}\text { Serial } \\
\text { number of } \\
\text { mixture } \\
\text { ratio }\end{array}$} & \multirow{2}{*}{$\begin{array}{l}\text { Number of } \\
\text { mixture ratio }\end{array}$} & \multicolumn{2}{|c|}{$\begin{array}{l}\text { 7d consolidation } \\
\text { strength(MPa) }\end{array}$} \\
\hline & & $\begin{array}{l}\text { Rupture } \\
\text { strength }\end{array}$ & $\begin{array}{l}\text { Compressive } \\
\text { strength }\end{array}$ & & & $\begin{array}{l}\text { Rupture } \\
\text { strength }\end{array}$ & $\begin{array}{l}\text { Compressive } \\
\text { strength }\end{array}$ \\
\hline H01 & C6V1.0S21+N & 0.63 & 4.4 & H09 & C8V1.0S21+N & 0.59 & 3.2 \\
\hline H02 & C6V1.0S25+N & 0.76 & 4.1 & H10 & C8V1.0S25+N & 0.60 & 3.3 \\
\hline H03 & C6V1.0S29+N & 0.92 & 4.1 & H11 & C8V1.0S29+N & 0.80 & 5.0 \\
\hline H04 & C6V1.0S33+N & 0.90 & 6.5 & H12 & C8V1.0S33+N & 0.51 & 4.8 \\
\hline H05 & C7V1.0S21+N & 0.67 & 3.5 & H13 & C9V1.0S21+N & 0.60 & 3.4 \\
\hline H06 & C7V1.0S25+N & 0.56 & 3.6 & H14 & C9V1.0S25+N & 0.40 & 3.1 \\
\hline H07 & C7V1.0S29+N & 0.80 & 4.6 & H15 & C9V1.0S29+N & 0.56 & 3.8 \\
\hline H08 & C7V1.0S33+N & 0.55 & 4.5 & H16 & C9V1.0S33+N & 0.56 & 4.9 \\
\hline \multicolumn{8}{|c|}{ Table5 28d consolidation strength of double fluid grouting material } \\
\hline \multirow{2}{*}{$\begin{array}{l}\text { Serial } \\
\text { number of } \\
\text { mixture } \\
\text { ratio }\end{array}$} & \multirow{2}{*}{$\begin{array}{l}\text { Number of } \\
\text { mixture ratio }\end{array}$} & \multicolumn{2}{|c|}{$\begin{array}{l}\text { 28d consolidation } \\
\text { strength(MPa) }\end{array}$} & \multirow{2}{*}{$\begin{array}{l}\text { Serial } \\
\text { number of } \\
\text { mixture } \\
\text { ratio }\end{array}$} & \multirow{2}{*}{$\begin{array}{l}\text { Number of } \\
\text { mixture ratio }\end{array}$} & \multicolumn{2}{|c|}{$\begin{array}{l}\text { 28d consolidation } \\
\text { strength(MPa) }\end{array}$} \\
\hline & & $\begin{array}{l}\text { Rupture } \\
\text { strength }\end{array}$ & $\begin{array}{l}\text { Compressive } \\
\text { strength }\end{array}$ & & & $\begin{array}{l}\text { Rupture } \\
\text { strength }\end{array}$ & $\begin{array}{l}\text { Compressive } \\
\text { strength }\end{array}$ \\
\hline H01 & C6V1.0S21+N & 1.04 & 5.8 & H09 & $\mathrm{C} 8 \mathrm{~V} 1.0 \mathrm{~S} 21+\mathrm{N}$ & 0.66 & 5.1 \\
\hline H02 & $\mathrm{C} 6 \mathrm{~V} 1.0 \mathrm{~S} 25+\mathrm{N}$ & 0.80 & 7.0 & $\mathrm{H} 10$ & $\mathrm{C} 8 \mathrm{~V} 1.0 \mathrm{~S} 25+\mathrm{N}$ & 0.87 & 5.1 \\
\hline H03 & $\mathrm{C} 6 \mathrm{~V} 1.0 \mathrm{~S} 29+\mathrm{N}$ & 1.09 & 6.4 & H11 & $\mathrm{C} 8 \mathrm{~V} 1.0 \mathrm{~S} 29+\mathrm{N}$ & 0.87 & 5.1 \\
\hline H04 & $\mathrm{C} 6 \mathrm{~V} 1.0 \mathrm{~S} 33+\mathrm{N}$ & 1.50 & 8.4 & H12 & $\mathrm{C} 8 \mathrm{~V} 1.0 \mathrm{~S} 33+\mathrm{N}$ & 1.33 & 8.3 \\
\hline H05 & C7V1.0S21+N & 0.98 & 5.8 & H13 & C9V1.0S21+N & 0.66 & 5.8 \\
\hline H06 & C7V1.0S25+N & 0.97 & 5.3 & H14 & C9V1.0S25+N & 0.73 & 5.0 \\
\hline H07 & C7V1.0S29+N & 0.99 & 6.2 & H15 & C9V1.0S29+N & 0.98 & 5.4 \\
\hline H08 & C7V1.0S33+N & 1.26 & 8.3 & H16 & C9V1.0S33+N & 1.19 & 4.2 \\
\hline
\end{tabular}

\section{Data Analysis}

According to the experimental data of consolidation strength in Table 4 and table 5, when water cement ratio is certain, the influence diagram of Baume can be respectively made on $7 \mathrm{~d}$ and 28d rupture strength, compressive strength of grouting material(Fig.1).

The analysis from fig.1: when the cement slurry water cement ratio is certain, consolidation strength of double liquid grouting material with the increase of Sodium silicate grout Baume shows increasing trend.

The analysis of the phenomenon, Sodium silicate grout plays a procoagulant role in double liquid grouting material, mixing the suitable Baume Sodium silicate slurry and cement slurry can make the degree of consolidation reaction reach the maximum, the concretion body dense, greater consolidation strength, to improve rupture and compressive strength of consolidation body.

\section{Conclusion and prospect}

Through the measurement and comparative analysis of C-S double liquid grouting material of consolidation strength, can be clearly found: when change the Sodium silicate grout Baume, the effect on early consolidation strength of C-S double liquid grouting material is obvious, while the later consolidation strength in general is relatively stable. When the water cement ratio of cement slurry are 0.7, 0.8, Sodium silicate Baume are 21, 25, 29, consolidation strength of the prepared C-S double liquid grouting material is relatively stable, can do a further study. 

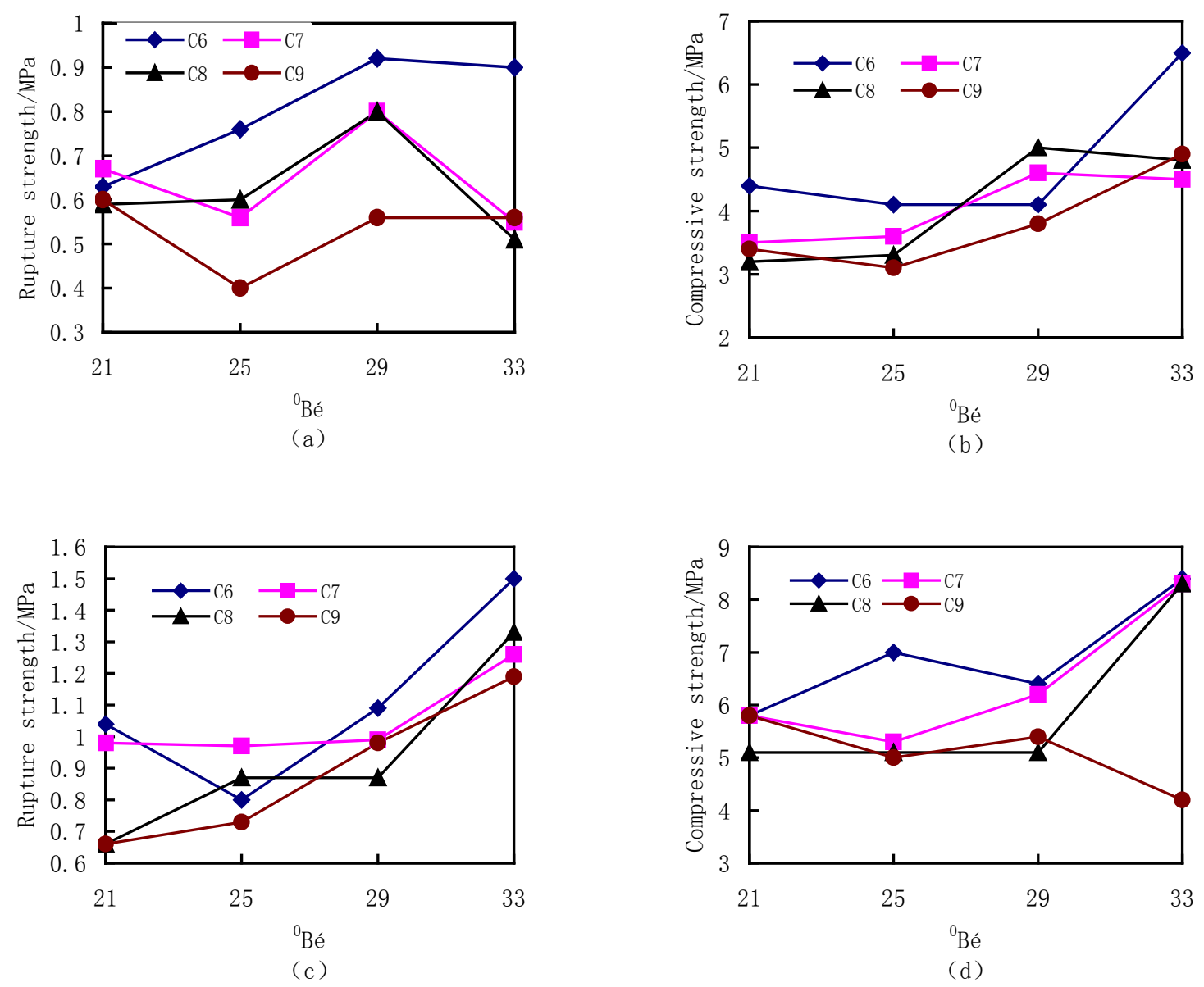

a: 7d rupture; b: 7d compression; c: 28d rupture; $d$ : 28d compression

Fig.1 Effect of ${ }^{0}$ Bé on the strength of consolidation with different W/C

\section{Acknowledgements}

The experimental study from the Zhangjiakou Municipal Science and Technology Bureau and the seismic research project (1321011B).

\section{References}

[1]JGJ/T 211-2010, Construction of cement-Sodium silicate double liquid grouting technical specification [S].

[2] GB 50025-2004, Building standard in collapsible loses plateau[S].

[3] HG/T 20691-2006, Technical regulations of high pressure jet grouting construction operation [S].

[4] X.J. Xue: Brief discussion on treatment of collapsible loess foundation[J]. Chinese western science and technology(2010).

[5] Y. Zhang, Q. Chen: Application of sodium silicate in building materials[J]. Choingqing Building(2012).

[6] Q. Y. Gao, Buidling Materials[M]. The fourth edition, Wuhan: Wuhan University of Technology Press(2012). 